\title{
Analisis Pengaruh Upah, Tingkat Pendidikan, Jenis Kelamin, Dan Usia Terhadap Produktifitas Tenaga Kerja Pada Sektor Industri Tenun Ikat Di Kota Kediri
}

\author{
Kartika Candra K. S; Budi Heryanto; Sri Rochani \\ Fakultas Ekonomi - Universitas Kadiri \\ E-mail : budiheryanto@unik-kediri.ac.id
}

\begin{abstract}
Productivity is one aspect in driving the progress of an industry and economic growth. Increasing productivity to help the existing economic development in order to realize the common goal of equalizing the welfare of the community. Therefore, it is necessary to have a good cooperation between the owner of the industry and the workforce in order to increase the productivity of the workforce in order to achieve equal distribution of the welfare of the community. The higher productivity of labor will increase industrial progress. But many factors can affect the high and low productivity of the workforce. Therefore what will be analyzed are: 'wages, education level, gender, and age for labor productivity in the woven weaving industry sector in Kota Kediri. The purpose of this study was to determine the effect of 'wages, education level, gender, and age on labor productivity in the woven weaving industry in Kota Kediri. This study uses questionnaires, documentation and direct interviews with 60 respondents in the ikat weaving industry in Kediri City. This research is a quantitative research with SPSS analysis tools. The results of this study indicate the variables of wages, education level, gender and age on the productivity of "labor in the weaving industry in Kota Kediri."
\end{abstract}

Keywords: Wages, Education Level, Gender, Age, Productivity

\begin{abstract}
ABSTRAK
Produktifitas adalah salah satu aspek dalam mendorong kemajuan sebuah industri dan pertumbuhan ekonomi. Peningkatan produktifitas guna membantu pembangunan ekonomi yang ada agar dapat mewujudkan tujuan bersama yakni pemerataan kesejahterahan masyarakat. Maka dari itu perlu adanya sebuah kerjasama yang baik antara pemilik industri dan tenaga kerja guna meningkatkan produktifitas tenaga kerja agar dapat mencapai pemerataan kesejahterahan masyarakat. Semakin tinggi produktifitas tenaga kerja maka akan meningkatkan kemajuan industri. Namun banyak faktor yang dapat mempengaruhi tinggi rendahnya produktifitas tenaga kerja. Oleh karena itu yang akan di analisis yaitu: 'upah, tingkat pendidikan, jenis kelamin, dan usia terhadap produktifitas tenaga kerja pada sektor industri tenun ikat di Kota Kediri'. Tujuan dari peneltian ini adalah untuk mengetahui pengaruh 'upah, tingkat pendidikan, jenis kelamin, dan usia terhadap' produktifitas tenaga kerja pada industri tenun ikat di Kota Kediri'. Penelitian ini menggunakan kuesioner, dokumentasi dan wawancara secara langsung pada 60 Responden tenaga kerja industri tenun ikat di Kota Kediri. Penelitian ini adalah jenis penelitian kuantitatif dengan alat analisis SPSS. Hasil dari penelitian ini menunjukkan antara variabel upah, tingkat pendidikan, jenis kelamin dan usia terhadap produktifitas 'tenaga kerja pada industri tenun ikat di Kota Kediri'.
\end{abstract}

Kata kunci : Upah, Tingkat Pendidikan, Jenis Kelamin, Usia, Produktifitas 


\section{PENDAHULUAN}

"Menurut (Herawati 2013)". Pembangunan taraf hidup masyarakat meningkat atau dengan kata lain kehidupan masyarakat menjadi lebih sejahtera dibandingkan sebelumnya. Tingkat taraf hidup masyarakat dapat diukur dari tingkat pendapatan riil per kapita. Semakin tinggi tingkat pendapatan maka semakin tinggi tingkat kesejahterahan masyarakat.

Pembangunan ekonomi tidak dapat dilakukan secara terpisah. Pembangunan ekonomi suatu daearah atau suatu negara haruslah saling berkesinambungan agar dapat mencapai pembangunan ekonomi yang merata. Pembangunan yang direncanakan atau yang akan dilakukan pemerintah daerah harus bisa mendukung pembangunan yang dilakukan pemerintah pusat agar dapat mengoptimalkan peningkatan perekonomian negara. Salah satu upaya negara untuk meningkatkan perekononomian dapat dilakuakan melalui sektor industri.

Kebutuhan akan sumber daya manusia yang berkualitas mampu meningkatkan produktivitas dari setiap tenaga kerja. Dengan meningkatnya produktifitas tenaga kerja maka akan lebih banyak produk yang akan dihasilkan dan dapat menambah pemasukan industri yang akan mewujudkan kemajuan industri tersebut (Panjaitan \& Djunaedi, 2017). Tingkat pendidikan diperlukan untuk setiap individu karena dengan adanya pendidikan akan meningkatkan kualitas dari tenaga kerja itu sendiri.

Upah, jenis kelamin, dan usia juga ikut mementukan seberapa besar produktifitas tenaga kerja pada suatu industri. Upah digunakan untuk memotivasi tenaga kerja agar meningkatkan produktifitasnya. Upah yang layak diharapkan dapat mendorong tenaga kerja bekerja lebih giat dan rajin sehingga bisa meningkatkan produktifitasnya. Jenis kelamin dan usia juga digunakan untuk mengoptimalkan produktifitas tenaga kerja sesuai keahlian, kekuatan, dan ketelitian agar pekerjaan yang dialakukan sesuai porsi dari kekuatan tenaga kerja yang diharapkan akan lebih mengefienkan waktu dan dapat menghasilkan lebih banyak produksi pada industri. Jenis kelamin disesuaikan dengan porsi kekuatan yang mungkin bisa dilakukan tanpa memberatkan tenaga kerja. Jenis kelamin juga bisa digunakan sebagai salah satu alasan untuk lebih meningkatkan produktifitas dengan mengoptimalkan keahlian dan ketelitian. Tenaga kerja wanita tidak lebih baik dari tenaga kerja pria maupun sebaliknya. Pembagian tugas bagi tenaga kerja mungkin akan lebih efektif dalam 
meningkatkan produktifitas, "Namun dalam keadaan tertentu terkadang produktifitas perempuan lebih tinggi dibanding laki-laki, misalnya pekerjaan yang membutuhkan ketelitian dan kesabaran (Amron, 2009)". Sedangkan tenaga kerja pria ditempatkan pada bagian yang membutuhkan kecepatan dan kekuatan yang lebih. Usia juga dapat mempengaruhi produktifitas tenaga kerja karena dengan bertambahnya usia juga dapat mempengaruhi produktifitas tenaga kerja. Usia dari setiap tenaga kerja memperngaruhi produktifitasnya karena tenaga kerja yang memiliki usia lebih tua mungkin tidak lebih cepat dan produktif dibandingkan dengan tenaga kerja yang berusia lebih muda. Namun tidak menutup kemungkinan bahwa tenaga kerja yang lebih muda juga tidak lebih berpengalaman dengan tenaga kerja yang lebih tua, karena dengan adanya pengalaman akan membuat sebuah perbedaan. Dengan pengalaman kerja yang banyak maka tenaga kerja akan lebih mudah dan cepat mengambil keputusan dan mengatasi masalah yang mungkin muncul selama bekerja.

Kota Kediri merupakan salah satu kota di Jawa Timur yang memiliki aset pariwisata yang cukup potensial untuk dikembangkan, baik obyek wisata alam, budaya dan sejarah. Sebagai daya tarik wisata pemerintah Kota Kediri telah mengelompokkan IKM yang berbasis ekonomi kreatif, dimana IKM ini menjadi produk unggulan Kota Kediri yang terdiri dari IKM kuliner hingga kerajinan (Dewandaru \& Purnamaningsih, 2017).

Dalam mengembangkan pembangunan ekonomi di sektor indutri, pemerintah Kota Kediri mengadakan dan melaksanakan program pengembangan sektor industri kecil dan menengah (Dewandaru \& Purnamaningsih, 2017). Pengembangan sektor industri kecil dan menengah ini bertujuan untuk meningkatkan hasil penjualan dari industri kecil dan menengah dan juga membuka usaha untuk lebih membesarkan industri kecil dan mengengah itu sendiri. Berikut adalah beberapa produk unngulan dari industri kecil dan menengah (IKM) yang ada di Kota Kediri :

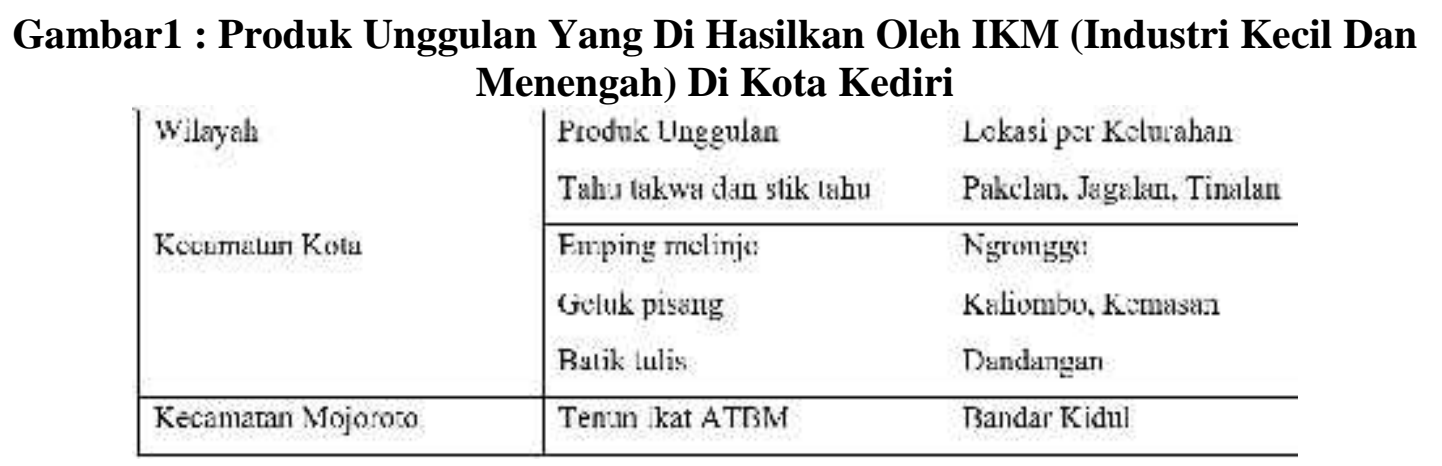


Sumber : kedirikota.go.id

Sentra tenun ikat yang berada di Kelurahan Bandar Kidul, Kecamatan Mojoroto, Kota Kediri sudah berdiri sejak puluhan tahun yang lalu yang masih dilanjutkan dan diteruskan oleh generasi penerus mereka. Industri tenun ikat ini telah membuktikan bahwa dengan kemajuan jaman tidak memberikan pengaruh yang terlalu besar hingga menyebabkan industri tenun ikat ini tidak dapat bertahan dalam persaingan pasar. Puluhan pengrajin tenun ikat ini mampu membuktikan bahwa mereka mampu bersaing dengan produk-produk baru yang mulai bermunculan sehingga industri tenun ikat ini mampu bertahan di berbagi macam kondisi perekonomian yang ada. Di Kelurahan Bandar Kidul sampai sekarang masih aktif dalam kegiatan industri tenun ikat, bahkan semakin bertambah pula para pengrajin tenun ikat disana. Sampai saat ini ada 12 merek dan bila di totalkan para karyawan yang bekerja ada kurang lebih 300 karyawan. Dengan keadaan yang demikian ini menunjukkan bahwa adanya kerjasama yang baik antara pemilik dan pekerja dalam meningkatkan produktifitas untuk tetap bisa menjalankan industri tenun ikat ini. Produktifitas yang baik dan terus meningkat hingga saat ini juga mendorong kemajuan industri tenun ikat sehingga dapat bertahan bahkan bertambah hinnga saat ini.

\section{TINJAUAN PUSTAKA}

\section{Pengertian Tenaga Kerja}

Menurut Wilson Bangun (2017) sumber daya manusia dapat di kategorikan ke dalam sumber daya manusia terampil (skilled human resource) dan tenaga kerja tidak terampil (unskilled human resource). Sumber daya manusia terampil adalah tenaga kerja yang berpendidikan minimal sekolah lanjutan tingkat atas (senior high school) dan perguruan tinggi (university) atau memiliki pengetahuan setara dengan itu. Sedangkan, sumber daya manusia tidak terampil adalah tenaga kerja berpendidikan sekolah lanjutan tingkat pertama ke bawah (junior high school to bottom).

\section{Teori Penawaran Tenaga Kerja}

Menurut Santoso (2012) penawaran tenaga kerja adalah hubungan antara tingkat upah mempengaruhi jumlah tenaga kerja karena dengan tingkat upah yang tinggi maka tenaga kerja juga bisa meningkatkan tingkat kesejahterahan keluarga. Tujuan awal 
bekerja adalah untuk bisa meningkatkan kesejahterahan tenaga kerja maka dari itu tingkat upah menjadi salah satu pertimbangan masing-masing tenaga kerja untuk memilih suatu pekerjaan.

Menurut Bellante (dalam Mahendra 2014) begitu juga dengan penawaran tenaga kerja. Tingginya tingkat upah akan mempengaruhi tingkat penawaran tenaga kerja, semakin tinggi tingkat upah akan semakin meningkatkan jumlah penawaran tenaga kerja yang ada. Menurut Simanjuntak (Herawati, 2013) dan semakin rendahnya tingkat upah juga akan mengurangi penawaran tenaga kerjaa dan meningkatkan permintaan tenaga kerja dari sisi produsen.

\section{Pengertian Produktifitas}

Menurut Ardika (dalam Almira 2016) bahwa produktifitas tenaga kerja adalah kemampuan seseorang dalam menghasilkan suatu pekerjaan yang lebih banyak dari pada ukuran biasan yang telah umum.

Menurut Simanjuntak (dalam Mahendra, 2014), produktifitas istilah produktifitas (productivity) hasilkan seorang pekerja per jam kerja (Mankiw dalam Lestari 2011). Produktofitas adalah perbandingan antara output dan input, atau dalam pengertian lain disebutka bahwa produktifitas Menurut Sinungan (dalam Lestari 2011) produktifitas suatu perbandinagan dan merupakan suatu pengkuran

\section{Pengertian Upah}

Menurut Flippo (dalam AL-amin, 2015) menyatakan bahwa upah merupakan seseorang kepada orang lain.

\section{Pengertian Tingkat Pendidikan}

Menurut Flippo (dalam Hermawan, 2017) pendidikan adalah berhubungan dengan peningkatan pengetahuan umum dan pemahaman atas lingkungan kita secara menyeluruh. Menurut Rukky (dalam Hermawan, 2017) pendidikan (learning) adalah tindakan yang dilakukan oleh pihak karyawan dalam upaya menguasai, keterampilan, pengetahuan, dan sikap tertentu yang mengakibatkan perubahan yang relatif bersifat permanen dalam perilaku kerja mereka. 
Menurut Hermawan (2017) pendidikan merupakan suatu proses yang berkesinambungan yang tidak dapat dipisahkan dari sistem organisasi. meningkatkan produktifitas kerja. Adanya pegawai yang baru dan yang akan menempati posisi baru, mendorong pehak kepegawaian senantiasa menyelenggarakan program pendidikan dan pelatihan.

\section{Pengertian Jenis Kelamin}

Menurut Hungu (dalam Putri, 2016) jenis kelamin (seks) adalah perbedaan antara perempuan dengan laki-laki secara biologis sejak seorang itu dilahirkan. Perbedaan biologis dan fungsi biologis laki-laki dan perempuan tidak dapat dipertukarkan diantara keduanya, dan fungsinya tetap dengan laki-laki dan perempuan yang ada di muka bumi.

Menurut Simanjuntak (dalam Putri, 2016). Dari uraian diatas dapat disimpulkan bahwa jenis kelamin adalah perbedaan mendasar antara laki-laki dan perempuan terutama secara biologis.

\section{Rasio Perbandingan Jumlah Perempuan Dan Laki-Laki}

Rasio jenis kelamin (sex ratio) adalah perbandingan antara jumlah penduduk laki-laki dan jumlah penduduk perempuan di suatu daerah atau negara pada suatu waktu tertentu. Untuk menegtahui rasio jenis kelamin menggunakan rumus :

$$
\mathrm{SR}=\frac{P}{P} \times 100
$$

\section{Pengaruh Antara Upah Dengan Produktifitas Tenaga Kerja}

Besar kecilnya upah yang diberikan perusahaan kepada para pekerjanya akan mempengaruhi tinggi rendahnya tingkat produktifitas kerja karyawan menurut Setiadi (dalam Herawati, 2013). Upah yang diberikan kepada tenaga kerja yang layak dan sesuai dengan pekerjaan yang ada maka akan mempengaruhi produktifitas karena dengan upah yang layak tenaga kerja akan bisa mencukupi kebutuhan hidupnya sehingga juga akan meningkatkan produktifitasnya. Sehingga ketika tingkat penghasilan cukup, akan menimbiulkan konsentrasi kerja dan mengarahkan kemampuan yang dimiliki untuk meningkatkan produktifitas menurut Kurniawan (dalam Herawati, 2013). 


\section{Pengaruh Antara Tingkat Pendidikan Dengan Produktifitas Tenaga Kerja}

Semakin tinggi tingkat pendidikan seseorang maka smakin tinggi juga tingkat produktifitas atau kinerja tenaga kerja tersebut menurut Simanjuntak (dalam Mahendra, 2014). Tingkat pendidikan memberikan pengaruh terhadap produktifitas tenaga kerja, dengan tingginya tingkat pendidikan maka akan memberikan pengetahuan untuk bisa meningkatkan produktifitas dan kinerja tentang pekerjaan yang sedang digeluti. Tingginya kesadaran akan pentingnya produktifitas, akan mendorong tenaga kerja yang bersangkutan melakukan tindakan yang produktif menurut Kurniawan (dalam Mahendra, 2014).

\section{Pengaruh Antara Jenis Kelamin Dengan Produktifitas Tenaga Kerja}

Adanya perbedaan jenis kelamin juga mempengaruhi produktiftas tenaga kerja. Berbagai perbedaan fisik yang ada antara laki-laki dan perempuan juga memberikan perbedaan produktifitas tenaga kerja, seperti tingkat produktifitas laki-laki mungkin akan lebih tinggi jika dibandingkan perempuan karena perempuan mempunyai fisik yang kurang kuat bila dibandingkan dengan fisik seorang laki-laki. Namun dalam keadaan tertentu terkadang produktifitas perempuan lebih tinggi dibandingkan laki-laki, misalnya pekerjaan yang membutuhkan ketelitian dan kesabaran menurut Amron (dalam Herawati, 2013).

\section{Pengaruh Antara Usia Dengan Produktifitas Tenaga Kerja}

Menurut Amron (dalam Mahendra, 2014). Namun tenaga kerja yang lebih muda tidak memiliki pengalaman kerja sebanyak yang dimiliki oleh tenaga kerja yang lebih tua.

\section{METODE PENELITIAN}

\section{Populasi Dan Sampel Penelitian}

Menurut Dajan (dalam Mahendra, 2014). Penelitian ini mengambil kasus di Kota Kediri Provinsi Jawa Timur. Responden yang akan di ambil dalam penelitian ini 
adalah di industri Tenun Ikat ATBM Bandar Kidul Kota Kediri yang berjumlah12 merek dengan karyawan yang bila ditotalkan berjumlah kurang lebih 300 orang.

\section{Metode Pengumpulan Data}

\section{Kuesioner}

menurut Kasmadi (dalam Hermawan, 2017). Jawaban dari setiap item yang menggunakan skala linkert mempunyai gradasi dari sangat positif hingga sangat negatif. Sementara untuk keperluan analisis kuantitatif diberikan skor sebagai berikut :
a. Sangat setuju
(SS) diberi skor 5
b. Setuju
(S) diberi skor 4
c. Netral
(N) diberi skor 3
d. Tidak setuju
(TS) diberi skor 2
e. Sangat tidak setuju (STS) diberi skor 1

2. Wawancara

3. Dokumentasi

\section{Metode Analisis Data}

Normalitas, Multikolonieritas, Heteroskedastristas

\section{Analisis Regresi Berganda}

Menurut Gujarati (dalam Mahendra, 2014). Metode OLS berusaha meminimalkan penyimpangan hasil perhitungan (regresi) terhadap kondisi aktual. Dalam menghasilkan estimasi persamaan yang baik, maka setiap estimator OLS harus memenuhi kritria BLUE (Best Linear Unbise Estimator), yaitu :

a. Estimator parameter ( $\beta \mathrm{i})$ bersifat linear terhadap variabel dependen.

b. Estimator parameter $(\beta \mathrm{i})$ bersifat tidak bias atau nilai rata-rata yang diharapkan sama dengan nilai $(\beta \mathrm{i})$ sesungguhnya.

c. Estimator $(\beta \mathrm{i})$ memiliki varian yang minimum, sehingga disebut efisien. 


\section{HASIL PENELITIAN DAN PEMBAHASAN}

\section{Analisis Regresi Berganda}

\begin{tabular}{|c|c|c|c|c|c|c|}
\hline \multicolumn{7}{|c|}{ Coefficients ${ }^{\mathrm{a}}$} \\
\hline \multirow{2}{*}{\multicolumn{2}{|c|}{ Model }} & \multicolumn{2}{|c|}{$\begin{array}{l}\text { Unstandardized } \\
\text { Coefficients }\end{array}$} & \multirow{2}{*}{$\begin{array}{l}\text { Standardized } \\
\text { Coefficients } \\
\text { Beta }\end{array}$} & \multirow[b]{2}{*}{$\mathrm{T}$} & \multirow[b]{2}{*}{ Sig. } \\
\hline & & B & Std. Error & & & \\
\hline \multirow[t]{5}{*}{1} & (Constant) & -8.208 & 9.561 & & -.858 & .394 \\
\hline & Upah & 1.529 & .447 & .405 & 3.419 & .001 \\
\hline & $\begin{array}{l}\text { Tingkat } \\
\text { Pendidikan }\end{array}$ & .680 & .316 & .287 & 2.153 & .036 \\
\hline & Jenis Kelamin & 5.477 & 2.688 & .172 & 2.038 & .046 \\
\hline & Usia & 1.543 & .557 & .387 & 2.772 & .008 \\
\hline
\end{tabular}

a. Dependent Variable: Produktivitas Kerja

Sumber : Data Primer Diolah Peneliti, (2019)

$\mathrm{Y}=8,208+1,529 \mathrm{X}_{1}+0,680 \mathrm{X}_{2}+5,477 \mathrm{X}_{3}+1,543 \mathrm{X}_{4}+\mathrm{e}$

Persamaan regresi tersebut mempunyai makna sebagai berikut :

1. Konstanta $=8,208$

Jika variabel $\left(\mathrm{X}_{1}\right),\left(\mathrm{X}_{2}\right),\left(\mathrm{X}_{3}\right)$, dan $\left(\mathrm{X}_{4}\right)=0$, maka $(\mathrm{Y})$ sebesar 0,836 .

2. Koefisien $X_{1}=1,529$

Setiap penambahan 1 satuan $\left(\mathrm{X}_{1}\right)$ dengan asumsi $\left(\mathrm{X}_{2}\right),\left(\mathrm{X}_{3}\right)$, dan $\left(\mathrm{X}_{4}\right)$ tetap dan tidak berubah, maka akan menaikkan (Y) sebesar 1,529 kali.

3. Koefisien $\mathrm{X}_{2}=0,680$

Setiap penambahan 1 satuan $\left(\mathrm{X}_{2}\right)$ dengan asumsi $\left(\mathrm{X}_{1}\right),\left(\mathrm{X}_{3}\right)$, dan $\left(\mathrm{X}_{4}\right)$ tetap dan tidak berubah, maka akan meningkatkan (Y) sebesar 0,680 kali.

4. Koefisien $\mathrm{X}_{3}=5,477$

Setiap penambahan 1 satuan $\left(\mathrm{X}_{3}\right)$ dengan asumsi $\left(\mathrm{X}_{1}\right),\left(\mathrm{X}_{2}\right)$, dan $\left(\mathrm{X}_{4}\right)$ tetap dan tidak berubah, maka akan meningkatkan (Y) sebesar 5,477 kali.

5. Koefisien $\mathrm{X}_{4}=1,543$

Setiap penambahan 1 satuan $\left(\mathrm{X}_{4}\right)$ dengan asumsi $\left(\mathrm{X}_{1}\right),\left(\mathrm{X}_{2}\right)$, dan $\left(\mathrm{X}_{3}\right)$ tetap dan berubah, maka akan meningkatkan (Y) sebesar 1,543 kali.

\section{Koefisien Determinasi $\left(\mathbf{R}^{2}\right)$}

\begin{tabular}{|c|c|c|c|c|c|}
\hline \multirow[b]{2}{*}{ Model } & \multirow[b]{2}{*}{$\mathrm{R}$} & \multirow[b]{2}{*}{ R Square } & Model Summary & \multirow{2}{*}{$\begin{array}{l}\text { Std. Error of } \\
\text { the Estimate }\end{array}$} & \multirow[b]{2}{*}{$\begin{array}{l}\text { Durbin- } \\
\text { Watson }\end{array}$} \\
\hline & & & $\begin{array}{ll}\text { Adjusted } & \mathrm{R} \\
\text { Square } & \end{array}$ & & \\
\hline 1 & $.911^{\mathrm{a}}$ & .830 & .818 & 6.76273 & 1.818 \\
\hline
\end{tabular}

a. Predictors: (Constant), Usia, Jenis Kelamin, Upah, Tingkat Pendidikan

b. Dependent Variable: Produktivitas Kerja

Sumber : Data Primer Diolah Peneliti, (2019)

Nilai $\mathrm{R}$ square sebesar 0,830 atau $0,830 \times 100 \%=83,0 \%$ dengan demikian menunjukkan bahwa X1, X2. X3, dan X4 dapat menjelaskan Y sebesar 83,0\% dan sisanya yaitu $17,0 \%$ dijelaskan variabel lain yang tidak dikaji dalam penelitian ini. 


\section{Hasil Hipotesis Secara Parsial (Uji t)}

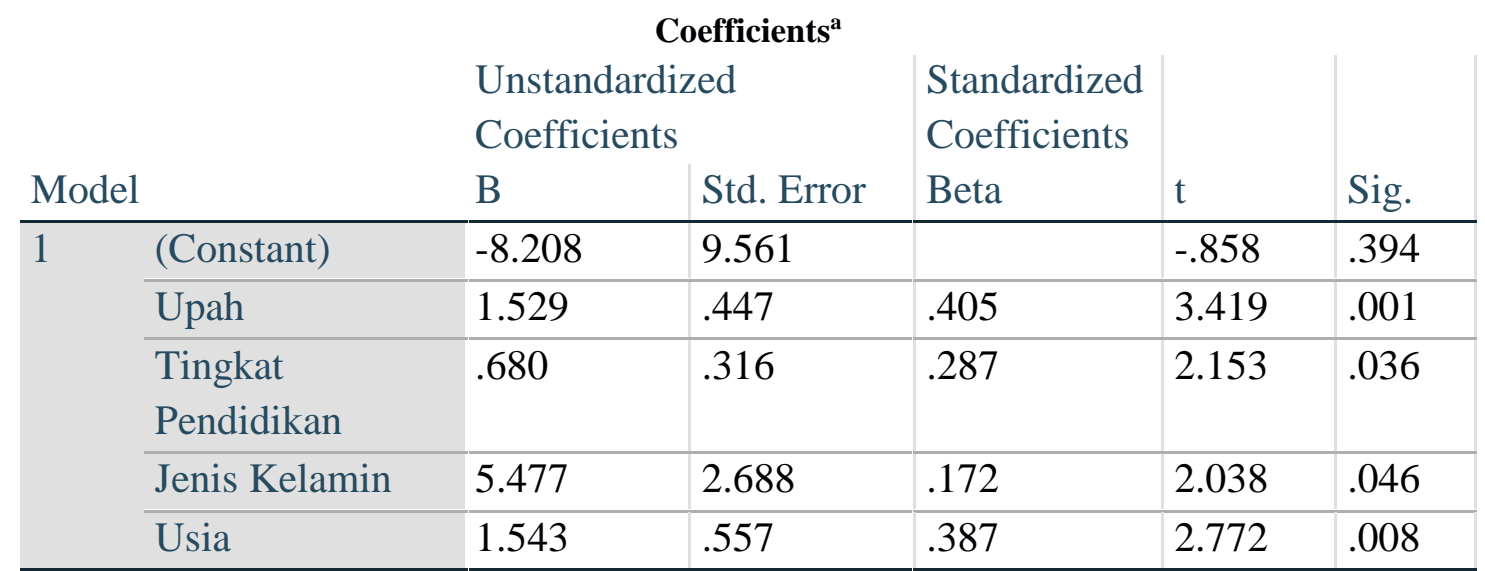

a. Dependent Variable: Produktivitas Kerja

Sumber : Data primer diolah peneliti, (2019)

1. Nilai t hitung variabel $\mathrm{X} 1$ lebih besar dari pada nilai $t$ tabel yaitu 3,419 $>2,001$. Hal ini berarti X1 secara parsial berpengaruh signifikan terhadap Y.

2. Nilai t hitung variabel $X 2$ lebih besar dari pada nilai t tabel yaitu 2,153>2,001. Hal ini berarti X2 secara parsial berpengaruh signifikan terhadap Y.

3. Nilai t hitung variabel $\mathrm{X} 3$ lebih besar dai pada nilai t tabel yaitu $2.038>2,001$. Hal ini berarti X3 secara parsial berpengaruh signifikan terhadap Y.

4. Nilai t hitung variabel $X 4$ lebih besar dari pada nilai t tabel yaitu 2,772 > 2,001. Hal ini berarti X4 secara parsial berpengaruh signifikan terhadap Y.

\section{Pembahasan}

Pengaruh Upah Terhadap Produktifitas Tenaga Kerja Pada Industri Tenun Ikat Di Kota Kediri.

Hasil analisis diketahui bahwa terdapat pengaruh positif upah terhadap produktifitas tenaga kerja pada industri tenun ikat di Kota Kediri yang diketahui dari nilai koefisien upah yang bertanda positif sebesar 1,529 dan signifikan kurang dari 0,05 yaitu 0,001. Serta nilai $\mathrm{t}$ hitung $>\mathrm{t}$ tabel $(3,419>2,001)$. Maka dapat disimpulkan bahwa variabel upah berpengaruh positif dan signifikan terhadap produktifitas tenaga kerja pada industri tenun ikat di Kota Kediri

\section{Pengaruh Tingkat Pendidikan Terhadap Produktifitas Tenaga Kerja Pada Industri Tenun Ikat Di Kota Kediri.}


Hasil analisis diketahui dari nilai koefisien tingkat pendidikan yang bertanda positif sebesar 0,680 dan signifikan kurang dari 0,05 yaitu 0,036. Serta nilai t hitung $>\mathrm{t}$ tabel $(2,153>2,001)$. Maka dapat disimpulkan bahwa tingkat pendidikan berpengaruh positif dan signifikan terhadap produktifitas tenaga kerja pada industri tenun ikat di Kota Kediri.

\section{Pengaruh Jenis Kelamin Terhadap Produktifitas Tenaga Kerja Pada Industri Tenun Ikat Di Kota Kediri.}

Dari hasil analisis diketahui bahwa terdapat pengaruh positif jenis kelamin terhadap produktifitas tenaga kerja pada industri tenun ikat di Kota Kediri yang diketahui dari nilai koefisien jenis kelamin yang bertanda positif sebesar 5,477 dan signifikan kurang dari 0,05 yaitu 0,046 . Serta nilai $\mathrm{t}$ hitung > t tabel $(2,038>2,001)$. Maka dapat disimpulkan bahwa variabel jenis kelamin berpengaruh positif dan signifikan terhadap produktifitas tenaga kerja tenun ikat di Kota Kediri.

\section{Pengaruh Usia Terhadap Produktifitas Tenaga Kerja Pada Industri Tenun Ikat Di Kota Kediri.}

Dari hasil analisis diketahui bahwa terdapat pengaruh positif usia terhadap produktifitas tenaga kerja pada industri tenun ikat di Kota Kediri yang diketahui dari nilai koefisien yang bernilai positif sebesar 1,543 dan signifikan kurang dari 0,05 yaitu 0,008. Serta nilai $\mathrm{t}$ hitung $>\mathrm{t}$ tabel $(2,772>2,001)$. Maka dapat disimpulkan bahwa variabel usia berpengaruh positif dan signifikan terhadap produktifitas tenaga kerja pada industri tenun ikat di Kota Kediri.

\section{KESIMPULAN DAN SARAN}

\section{Kesimpulan}

Berdasarkan hasil penelitian dan pembahasan, maka dapat diambil suatu kesimpulan sebagai berikut :

1. Hasil penelitian menunjukkan ada pengaruh positif dan signifikan antara variabel upah terhadap produktififtas tenaga kerja. Diketahui dari nilai koefisien yang bertanda positif dan signifikan kurang dari 0,05 serta nilai t hitung yang lebih dari $\mathrm{t}$ tabel $(3,419>2.001)$. Hal ini karena upah adalah salah satu motivasi dari tenaga 
kerja untuk meningkatkan produktifitasnya. Dan di industri tenun ikat ini menerapkan sistem kerja borongan yang berarti jika menginginkan upah yang tinggi maka produktifitas tenaga kerja juga harus tinggi.

2. Hasil penelitian menunjukkan bahwa ada pengaruh positif dan signifikan antara variabel tingkat pendidikan terhadap produktifitas tenaga kerja. Diketahui dari nilai koefisien yang bertanda positif dan signifikan kurang dari 0,05 serta nilai t hitung yang lebih besar dari $\mathrm{t}$ tabel $(2,153>2,001)$. Dalam kenyataannya tingkat pendidikan pada industri tenun ikat di Kota Kediri ini tidak begitu berpengaruh, karena ada pengajaran untuk tenaga kerja baru yang akan bekerja. Sehingga tidak selalu produktifitas yang tinggi berasal dari tenaga kerja yang memiliki pendidikan yang lebih tinggi.

3. Jenis kelamin berpengaruh positif dan signifikan terhadap produktifitas tenaga kerja. Hal ini didasarkan pada nilai koefisien yang bertanda positif dan signifikan kurang dari 0,05 serta $t$ hitung yang lebih besar dari t tabel $(2,038>2,001)$. Terdapat pembagian kerja sesuai gender untuk tenaga kerja yang bekerja pada industri tenun ikat ini yang membuat tenaga kerja bekerja sesuai porsi kekuatan masing-masing, sehingga tidak ada tenaga kerja yang harus bekerja lebih keras dari semestinya yang juga akan mempengaruhi produktifitas dari masing-masing tenaga kerja.

4. Usia berpengaruh positif dan signifikan terhadap produktifitas tenaga kerja. Hal ini didasarkan pada nilai koefisien yang bertanda positif dan signifikan kurang dari 0,05 serta $t$ hitung yang lebih besar dari t tabel $(2,772>2,001)$. Perbedaan usia mempengaruhi produktifitas tenaga kerja karena dengan bertambahnya usia umumnya akan menurunkan peforma dan ketangkasan dalam bekerja dan juga menurunnya tingkat kesehatan. Sehingga produktifitas yang dihasilkan tidak akan sama dari masing-masing tenaga kerja yang harus menyesuaikan dengan situasi dan kondisi yang dialami.

\section{Saran}

1. Bagi Peneliti Selanjutnya

Sebagai referensi penelitian yang akan dilakukan, namun mungkin bisa mengangkat variabel yang berbeda dan lebih menggali permasalahan atau keresahan yang muncul 
pada industri tenun ikat ini. Agar bisa lengkapi data yang telah tersedia maka diharapkan penggunaan data menggunakan data yang lebih baru dan dapat menemukan masalah-masalah baru yang mungkin muncul di kemudian hari agar informasi yang diterima lebih lengkap dan akurat. Sehingga dalam penelitian selanjutnya dapat menjelaskan lebih dalam mengenai variabel-variabel yang berpengaruh dalam industri tenun ikat.

\section{Bagi Industri}

Diharapkan dengan adanya penelitian ini menjadikan industri tenun ikat lebih baik dan lebih maju. Dengan adanya hasil dari penelitian ini peneliti mengharapkan pemilik industri lebih memperhatikan kesejahterahan tenaga kerja, karena dengan meningkatnya kesejaterahan tenaga kerja maka akan dapat memotivasi tenaga kerja untuk bekerja dengan lebih giat dan selalu mencoba men9ngkatkan produktiftasnya. Adanya timbal balik yang baik antara pemilik industri dengan tenaga kerja akan membuat industri berkembang dengan baik dan dapat bertahan di dalam persaingan bisnis.

\section{Bagi Pemerintah}

Industri tenun ikat di Desa Bandar Kidul Kota Kediri ini adalah salah satu produk unggulan di Kota Kediri. Agar produk ini bisa lebih berkembang diharapkan pemerintah membantu dan mendukung proses pemasarannyaagar supaya produk tenun ikat ini lebih dikenal atau bahkan bisa menjadi desa wisata edukasi agar bisa menjadi suatu nilai tambah bagi Kota Kediri khususnya bagi masyarakat sekitar.

\section{DAFTAR PUSTAKA}

Al-amin, Maratin Nafiah. 2015. "Pengaruh Upah, Disiplin Kerja Dan Insentif Terhadap Produktifitas Tenaga Kerja Minimarket Rizky Di Kabupaten Sragen”. Skripsi. Fakultas Ekonomi Universitas Negeri Yogyakarta.

Almira. 2016. "Pengaruh Tingkat U pah, Pengalaman Kerja, dan Tingkat Pendidikan Terhadap Produktifitas Individual Tenaga Pengajar Lembaga Kursus Bahasa Asing di Bandar Lampung (Studi Kasus English Fisrt (EF))". Skripsi. Fakultas Ekonomi Dan Bisnis Universitas Lampung.

Bangun, Wilson. 2017. Manajemen Sumber Daya Manusia Hubungan Industrial. Bandung: Erlangga.

Barthos, basir. 2012. Manajemen Sumber Daya Manusia Suatu Pendekatan Makro. Jakarta: Bumi Aksara.

Dewandaru, B., \& Purnamaningsih, N. (2017). Strategi Dalam Memajukan Industri Kreatif Dan Pengembangan Ekonomi Lokal Sebagai Daya Tarik Wisata (Studi Pada Kesenian Jaranan Di Kota Kediri). Ekonika: Jurnal Ekonomi Universitas 
Kadiri, 1(2).

Mahendra, A. D. (2014). Analisis pengaruh pendidikan, upah, jenis kelamin, usia dan pengalaman kerja terhadap produktivitas tenaga kerja (Studi di Industri Kecil Tempe di Kota Semarang), 1-87.

Panjaitan, H., \& Djunaedi, D. (2017). Product Advantage , Customer Relationship Marketing, and Service Quality on Customer Satisfaction of Bank Syariah Mandiri in Surabaya. International Review of Management and Marketing, 7(4), 122-130.

Herawati, Nur. 2013. "Analisis Pengaruh Pendidikan, U pah, Pengalaman Kerja, Jenis Kelamin, Dan Umur Terhadap Produktifitas Tenaga Kerja Industri Shutllecock Kota Tegal". Skripsi. Fakultas Ekonomi Dan Bisnis Universitas Diponegoro Semarang.

Hermawan, M. Agus. 2017. "Pengaruh Tingkat Pendidikan Dan Pengalaman Kerja Terhadap Produktifitas Kerja Dalam Perspektif Ekonomi Islam (Studi Pada Karyawan PT. Indokon Samudra Prrsada)". Skripsi. Fakultas Ekonomi Dan Bisnis Islam Universitas Islam Negeri Raden Intan Lampung.

Lestari, Ratih Widi. 2011. "Pengaruh Upah, Tingkat Pendidikan, Dan Teknologi Terhadap Produktifitas Tenaga Kerja Pada Industri Kecap Di Kecamatan Pati Kabupaten Pati" . Skripsi. Fakultas Ekonomi Universitas Negeri Semarang.

Mahendra, Adya Dwi. 2014. "Analisis Pengaruh Pendidikan, Upah, Jenis Kelamin, Usia Dan Pengalaman Kerja Terhadap Produktifitas Tenaga Kerja (Studi Di Industri Kecil Tempe Di Kota Semarang )". Skripsi. Fakultas Ekonomi Dan Bisnis Universitas Diponegoro Semarang.

Putri, Hanna Rianita. 2016. "Pengaruh Pendidikan, Pengalaman Kerja, Dan Jenis Kelamin Terhadap Produktifitas Kerja Karyawan Bagian Produksi CV.Karunia Abadi Wonosobo". Skripsi. Fakultas Ekonomi Universitas Negeri Yogyakarta.

Saidin. 2016. "Analisis Pengaruh U pah, Tingkat Pendidikan, Dan Teknologi Terhadap Produktifitas Tenaga Kerja Pada Industri Minyak Goreng Asli Mandar Di Kecamatan Banggae Timur Kabupaten Majene" . Skripsi. Fakultas Ekonomi Dan Bisnis Islam Universitas Islam Negeri Alauddin Makasar.

Santoso, Rokhedi Priyo. 2012. Ekonomi Sumber Daya Manusia dan Ketenagakerjaan. Yogyakarta: UPP STIM YKPN.

Saraswati, Lusy. 2016. "Pengaruh Tingkat Pendidikan, Lama Kerja, Jumlah Jam Kerja, Dan Usia Terhadap Upah Pekerja Wanita Industri Pengolahan Rambut Palsu Di Kabupaten Purbalingga”. Skripsi. Fakultas Ekonomi Dan Bisnis Islam Universitas Islam Negeri Sunan Kalijaga Yogyakarta.

Wibowo. 2011. Manajemen Kinerja Edisi Ketiga. Jakarta: Rajawali Pers. https://www.kedirikota.go.id/read/Investasi/31/1/49/Industri.html https://www.kedirikota.go.id/read/ProdukUnggulan/2014/12/29/3/6/6589/Tenun\%20ika $\underline{\mathrm{t}}$ https://teorionline.wordpress.com/tag/sampel-populasi-penelitian-teknik-sampling/ 